International Journal of Social Sciences and Humanities
Available online at http://sciencescholar.us/journal/index.php/ijssh
Vol. 2 No. 1, April 2018, pages: 56 64
e-ISSN: 2550-7001, p-ISSN: $2550-701 \mathrm{X}$
http://dx.doi.org/10.29332/ijssh.v2n1.80

\title{
The Meaning and Function of Woven Sarong on Muna Community
}

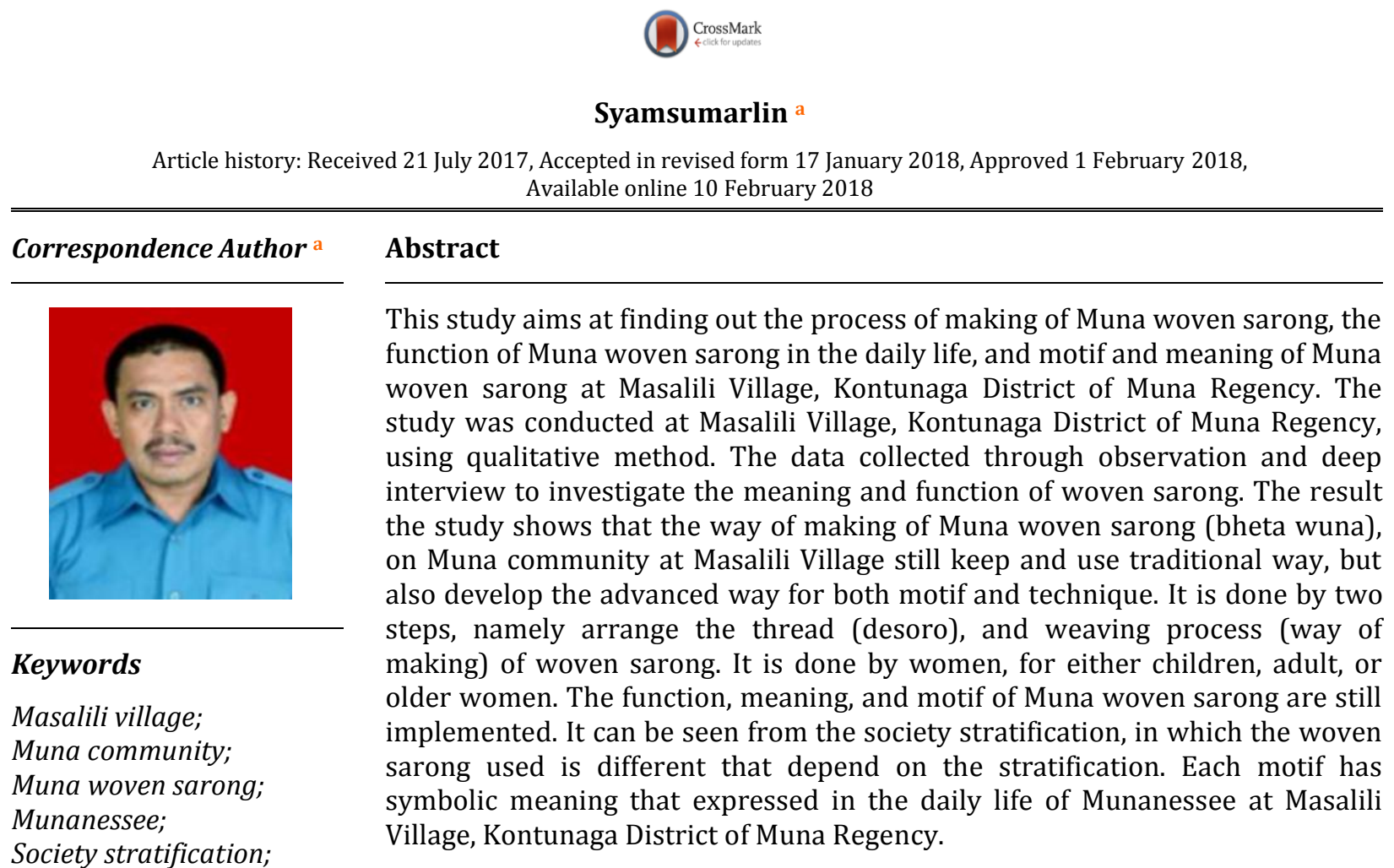

e-ISSN : 2550-7001, p-ISSN : 2550-701X ๑ Copyright 2018. The Author. SS Journals Published by Universidad Técnica de Manabí. This is an open-access article under the CC BY-SA 4.0 license (https://creativecommons.org/licenses/by-sa/4.0/) All rights reserved.

\section{Contents}

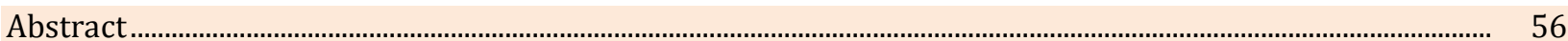

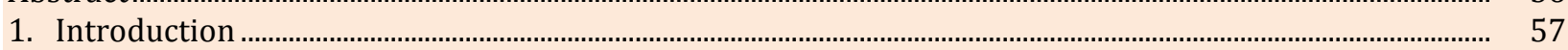

2. Research Method ..........................................................................................................................................................

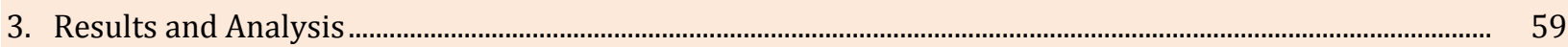

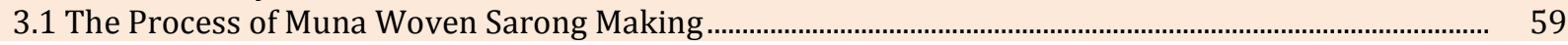

a Anthropology Department, Cultural Faculty of Halu Oleo University (syamsumarlinantrop@gmail.com) 
3.2 The Function of Muna Woven Sarong in the Munanessee Life.

4. Conclusion

Acknowledgements...

References.

Biography of Authors...

\section{Introduction}

Human being is the collective creature, so knowledge and skill of their collective life bases can be learnt by doing observation. When the human find out something that has advantages to solve the problems in the life, it will be redone when they face the similar problem. The behaviour pattern then will be communicated to men others in their collective, mainly to their generation. It then will be a custom that will be done in collective way.

Each community has different way in holding the custom ceremony, so various rituals performed found in each ethnic in Indonesia. The existence of culture is the characteristics and superiority of Indonesia. The culture diversity is performed by various ethnics in the archipelago area. One of them is matter culture like woven sarong for Muna ethnic. The society has special identity that they are different collective or unity. A community who live a certain area has particular characteristics. It can be seen from both abstract and physical dimensions. The elements of physical culture involve the tools that used for job, like tolls for planting plant, hunting, transportation, gun, ornament types, houses, and custom clothes including woven sarong. Each ethnic has different characteristics of the physical culture (Koentjaraningrat, 2005).

Related to the woven sarong, each ethnic has different characteristics. For example, woven sarong from Java is different to woven sarong from Bugis, Banjar, Aceh, and Tolaki. The differences are may be from model, motif, and the meaning for each motif. Arts is one of universal elements in human culture that function as to create the calm and quiet to human life. The arts is divided in two parts, fine arts (it relates to the eyesight) and voice arts (it relates to hearing). Those are the creation of human to fill the human needs, mainly to aesthethics values. Therefore, the arts always develop since it is needed by the human that supported by their knowledge.

One of the form of arts is woven sarong handicraft as the implementation of human creation. The woven sarong handicraft on each ethnic in Indonesian is various, like woven sarong in Muna, lungsin bundle woven in Toraja, bundle woven in Sumba, with various forms and motifs. Bundle woven on Sumba is used as symbolic creation with technology and arts dimensions. The symbolic means giving meaning for human authentic presence (Sofiah: 2011). Idea that become arts knowledge involves various meanings in the forms of arts. The meaning tends to as expressing of hope, balance, sadness, pain, irony, spirit, and motivation that supported by certain idea. The idea needs implementation and stabilization of values (Melalatoa and Sri Murni, 1997:52).

Woven thing is not only as dress but also it relates to aesthethics values, custom ceremony, religion, and status symbol in the community life. Kinds and motifs of certain woven dress are also used by certain people. The woven dress relates to the culture background and environment. Therefore, there are various woven dresses like bundle woven and batik (Melalatoa, 1991:242-243). Related to status symbol in the Sumba community life, the social stratification can be seen from both in the daily activity and custom performance, and from right and obligatory. To make the status will be clearer, it uses certain thing and animal in custom ceremony, death ceremony, or in the daily activity. Sumba culture divides several things are gold, silver, horse, and carabao; and with feminism types (ngau) like cloth (hinggi), sarong (lau), beads (mutisalak), and ivory (Melalatoa and Sri Murni, 1997). Further, women in Sumba from noble or kingdom class attend the wedding by using Lau Utu amahu (woven sarong with gold or silver), or Lau Utu hada (woven sarong with various coral ivories), or Lau Utu kau (woven sarong with snail ivories).

On Tolaki ethnic, design of sarong, mainly sawu ulu (sarong having head) consists of two big lines with three small lines, so it appears become five lines. Five vertical lines and five horizontal lines symbolizes the human body quality that involves right-lef side and above-under side covered by four spaces: East-West

Syamsumarlin, -. (2018). The Meaning and Function of Woven Sarong on Muna Community. International Journal Of Social Sciences And Humanities (IJSSH), 2(1), 56-64. doi:10.29332/ijssh.v2n1.80 
and North-South. In this case, Tolakinessee have expression as follow: Sawundo Wotolundo 'our sarong is our body quality' (Tarimana, 1989:248-249).

Knowledge of weaving has been known in Muna and even it spreads to all people in Muna. However, the knowledge of weaving is more decreasing in the present day. It is only found in several villages in Muna. One of them is in Masalili village, Kontunaga district of Muna regency. The knowledge and skill of weaving at Masalili village is obtained in hereditary way from one generation to other generation. The cloth from thread (cotton and silk) functions as not only dress or sarong but also has certain symbol in the daily life (Herusatoto: 1983). Woven sarong is not only become symbol for Sumba but also for Munanessee. For Munanessee, woven sarong is a symbol in their life. The symbol can be seen from kinds of sarong. The certain motif has certain meaning and used as guide in the life. Woven sarong has aesthethic values and symbolic meaning. It lines to statement of Maran (2000:43) that woven sarong from Palembang expresses cultural meaning and can be used for instrumental purposes, and build the happiness, patriot, brotherhood, and others based on the context of the use it.

According Turner (1989), symbol in ritual is social relation and social structure in the society to keep their social structure. Geertz (1973:88) states that symbol is norm with strong power in the implementation of sanction as a result of the existence of holy symbols as guide of life in the daily activity. Based on the statements above, Muna ethnic also has social symbols in the daily activity. One of them is the use of woven sarong. The ability of Munanessee in making woven sarong always consider status and role of society in the daily life.

Woven sarong on Muna ethnic, mainly at Masalili village, Kontunaga district of Muna regency, has different base motif and color. Although it has different color, Muna woven saronghas similar motif space or line, horizontal line (read Sofiah: 2011).

Woven sarong on Muna ethnic is called as bheta wuna 'Muna woven sarong'. Woven sarong used as status symbol in the daily life. Woven sarong on Masalili community has various motifs and functions. Each motif has different function and meaning. Based on the preminary study, Muna ethnic consists of several social stratifications, namely kaomu group (noble class), walaka group (custom class), and sara group (main custom class). Each group or class has certain motif and meaning. Likewise, there are also differences for each person, like motif and color for girl, motif and color for boy, motif and color for adult, widow, and widower. Based on the phenomena above, the research questions of the present study are (1) how are the process of making of Muna woven sarong at Masalili Village, Kontunaga District of Muna regency?; (2) what are the functions of Muna woven sarong in the daily life at Masalili Village, Kontunaga District of Muna regency?; and (3) what are the motifs and meanings of Muna woven sarong at Masalili Village, Kontunaga District of Muna regency?

\section{Research Method}

This study was conducted at Masalili Village, Kontunaga District of Muna Regency. The consideration of determination or choosing of this location is most of people at Masalili still keep the tradition of weaving of Muna sarong. Therefore, this study focuses on process of making of Muna woven sarong and the motifs and meanings of Muna woven sarong at Masalili village as culture inheritance from their ancestors. The data collected through participation observation and indepth interview. Participation observation used to investiage how the participation of people in weaving is, from determining color or motif, material, weaving process, until marketing. Indepth interview used to collect data about process of making of Muna woven sarong and the motifs and meanings of Muna woven sarong at Masalili village. Besides, it also includes data about natural environment (material stocks), demography (people group who do weaving and place where they do weaving), the history of woven sarong, people's knowledge of weaving, the motif, meaning, and kinds of woven sarong, and the process of weaving (goods and tools used in weaving), how long of weaving, and woven sarong for men and women.

It is descriptive qualitative study. It thus tries to create descriptive data, sistematic description, factual information, and accurate data in the field, and use ethnography method as the main method in data collection (Spradley: 1997). Therefore, it takes the informant by using purposive sampling with consideration they have much knowledge of Muna woven sarong and they are ready tobe interviewed. They consists of key or primary informant and secondary informant. The primary informant is head of village, since he has not only industry of Muna woven sarong but also has much knowledge of Muna woven 
sarong. The secondary informants are some weavers in this village. The data was analyzed descritively qualitatively to answer the research questions of the study. The data was firstly tabulated, and then interpreted by consideration of study aims, concept, and factual information in the field.

\section{Results and Analysis}

Woven sarong is one of human creation with important values in the society. Woven sarong with aesthethic values has functions in the daily life. In general, Muna woven sarong has been known and used to show the identity based on the stratification. The porcess of Muna woven sarong making, the function and meaning, and the motif of Muna woven sarong canbe seen in the illustration below.

\subsection{The Process of Muna Woven Sarong Making}

Woven sarong for Munanessee has closed relationship to stratification. Therefore, woven sarong is very important for Munanessee, mainly at Masalili Village. Woven sarong is used most at parties or ritual ceremonies. Woven sarong thus is very needed in the daily life. Therefore, most people at Masalili village work as weaver of Muna traditional woven sarong. The knowledge and skill of weaving on Muna people is learnt since they are in 12 years old. Even, it has been known by children of Munanessee when they are in five years old and they can do weaving in the age of 17 years old. The process of Muna woven sarong making traditionally consists of two phases as follow.

\section{Process of Arrange the Thread (Kasoro)}

Kasoro is the first process in making Muna woven sarong by arrangement each sheet of cloth at the provided tool and certain way. The main material base of Muna woven sarong is ordinary thread and nyilon thread with various color. Ordinary thread is a thread used by common people to weav, while nyilon thread is special thread used to make Muna woven sarong more bright.

Moreover, the process of kasoro is as follow. Kasori is done by two persons, one is in the right and other is in the left. They are in the medial between two stalks as the border of them. The border is called as jhangka. Besides jhangka, kaju, parambhibhita and bhibhita also put between two persons who will do weaving. Kaju is in the langku side, while parambhibhita and bhibhita is on the other stalks. It means that both persons have similar job or activity. They should do it carefully to create good quality sarong.

The next step is put thread into kaghua. The color of thread that put into kaghua has to suitable to the color of sarong will be made. In this case, the weaver should know how many sheets of thread used to make the suitable color of sarong. Muna woven sarong has different base colors, but in general it is only horizontal lines at the sarong. Besides lines, Muna woven sarong also has motifs. The color of thread used in doing kasoro is put into kaghua one by one. When certain color has been put into kaghua completely, it then uses other colors, and so on.

The next steps done in kasoro process is the thread in kaghua taken out or pull from at the edge, namely at top of sarong is moved below through parambhibhita and bhibhita. It then pull again and put above, and then move again under the cloth. Next, the thread in kaghua is pull again that accross through parambhibhita with bhibhita to make one thread and other threads are not mixed. After that, by using kangkai, a weaver pulls the thread through jhangka and then put into kaju. Other weaver also do the similar way, that is he/she pulls the thread through jhangka and then put into kaju. The thread then pulled through jhangka toward kaju. At kaju, the thread put into kaju again. The process is done repeatedly until the collection of thread form the sheet of sarong or cloth.

The problem faced in kasoro is when the quality of thread is not good. It may be the thread is very old or wet. It can decrease the quality of thread, and as a result is the threads are usually broken of. It also determines the quality of sarong. The quality of thread affetcs the quality of sarong. When the thread has good quality, it can create good cloth or sarong. In contrast, when the thread has bad quality, it can create bad cloth or sarong. Other factor that influence quality of sarong is the weavers. In this case, the factors of careness, dilligence, and patience of weavers really affect the quality of sarong.

After the kasoro process has been finished or done, the next step is weaving process. The weaving process determines what kinds of sarong will be made is.

Syamsumarlin, -. (2018). The Meaning and Function of Woven Sarong on Muna Community. International Journal Of Social Sciences And Humanities (IJSSH), 2(1), 56-64. doi:10.29332/ijssh.v2n1.80 
Process of Weaving

Process of weaving is a process to determine the kinds og sarong will be made in terms of motif or only pure sarong without motif. The weaving process should be done by the expert one. It needs special skill. Someone who do weaving is usually from older women or men because he/she has much experiences of weaving of custom sarong. He/she has firstly model or pattern of sarong that he/she will made, so the process of weaving run well and fluently.

The process of weaving can not be done by two persons but only one person. The fisrt step in weaving process is prepare the tools used like katai, kae, ati, kafetadaha, lobu, Katokano bunga, Kadanda, Bhalida, Kabuntuluha. Tetere, and Talikundo. After preparing the tools and move it from kasoro to weaving, the process of weaving can be done. The weaver sits in supine way. The leg of weaver put in the front toward kafetadaha. Next, by using lobu, the sheet of thread is put one by one into the cloth of kasoro through kaju and parambhibhita, and bhibhita. It then combined by using bhalida to hit jhangka repeteadly to make the thread more closed. After that, when the cloth become longer, to make the weaver does not feel difficulty, ati should be opened and the thread pulled again and closed to make it do not move. It is done in similar way repeteadly.

Making the motif in sheet of sarong needs special skill because it is very difficult. The difference motif needs different way of making. It is done usually by the older women or men who have much experients or knowledge of weaving. It also needs long time and has high difficulty level. Based on the result of observation in the field, the weaver who be able to make motif is above 35 years old. While, other weavers with age under 35 years old can make plain sarong only without motif or they can use nyilon thread to make the sarong looks beautifully. The kinds of produced sarong and the group of people who use it can be seen in the table below.

\begin{tabular}{|c|c|c|}
\hline No. & Social stratification & Kinds of sarong used \\
\hline \multirow{2}{*}{1} & \multirow{2}{*}{ Каоти } & Bhotu \\
\hline & & Samasili \\
\hline \multirow{2}{*}{2} & \multirow{2}{*}{ Sara } & Bharalu \\
\hline & & Manggo-Manggopa \\
\hline \multirow{4}{*}{3} & \multirow{4}{*}{ Walaka } & Kaso-Kasopa \\
\hline & & Lejha \\
\hline & & Bhia-Bhia \\
\hline & & Findang Konini \\
\hline
\end{tabular}

\subsection{The Function of Muna Woven Sarong in the Munanessee Life}

Muna woven sarong (bheta wuna) is one of creation that has important culture values for Munanessee. On Muna people, Muna woven sarong (bheta wuna) has important function in the daily life as an identity signer. Muna people as one of ethnics in Indonesian has custom or culture that related to stratification. In general, Muna people can be classified in three levels of stratification as follow:

a) Kaomu class (noble class)

b) Walaka class (custom class)

c) Sara class (religious leaders class)

Woven sarong that used by each class of people in the daily life is different depend on their stratification. The purpose is to know the class or the stratification of someone who use the certain woven sarong. In this case, the use of Muna woven sarong (bheta wuna) among classes of people is different. In the motif of Muna woven sarong and the way of use of Muna woven sarong, it can be determined which one come from Kaomu class (noble class), Walaka class (custom class), and which one come from sara class (religious leaders class). To differ those stratifications can be described below.

\section{For Men}

People from Kaomu and Walaka classes use a sheet of sarong based on the custom and the sarong does not pass their heel. Besides, those people use the sarong having "head" (fotono bheta) since they use kris, 
so their sarong on their left back are rather higher. In contrast, people from sara class use Muna woven sarong without "head".

\section{For Women}

Women from kaomu class use kabhantapi, and Muna woven sarong (bheta Wuna) that they use will be put on the knee (tewawono Tu). The women who use Muna woven sarong like this are women from noble class. Muna woven sarong for people from Kaomu class has bright color and motif. It means that Muna woven sarong becomes identity signer like identity for people from noble class. It is used commonly in the formal parties like wedding and other formal ritual ceremonies.

Women from Walaka class in using kabhantapi, Muna woven sarong (bheta Wuna) that they use is put under their knees (wepandano tu). The women who use Muna woven sarong like this are women from custom class. It means that Muna woven sarong becomes identity signer like identity for people from custom class, and become a part of culture at Masalili Village, Kontunaga District.

Women from Sara class in using Kabhantapi, Muna woven sarong (bheta Wuna) that they use is put under calf (tewawono ghaghe) or longer than women from noble class. It means that the women who use Muna woven sarong like this come from low class. It can be seen from their sarong that is longer. It shows that they are ready to be ordered or must follow the custom that has been determined by people from noble class. In the daily life, certain individu also has big role in giving the motif of Muna woven sarong. They are may be from older women/men (kamokula), girls (kalambe), teenagers (ana moghane), widow (bhirinanda), and widower (o duda).

The married women use two sheets of sarong (ratapi bheta), while unmarried women use only a sheet of sarong (setewu bheta). In any coidition, the unmarried women use only one sheet of sarong. Moreover, the widow still use two sheets of sarong. However, the color of her Muna woven sarong (bheta Wuna) is purple (warana o wunggo). The purpose is to differ married women (still has husband) and widow (bhirinanda). In the globalization era like in the present day, the use of Muna woven sarong (bheta Wuna) are different or does not follow the rule above. Muna woven sarong for older men/women (kamokula) also used by the children or girls (kalambe). Likewise, Muna woven sarong for girls also used by the children or boys (ana moghane).

In the past time, the people from low class can not use Muna woven sarong of noble classs (Koamu class) like Muna woven sarong which called as bharalu (bheta bharalu) for La Ode or Wa Ode. If the people from low class use bharalu (bheta bharalu), they will be given sanction. The sarong that they are using will be taken off forcely by other people.

\subsection{Motif and Meaning of Muna Woven Sarong}

Woven sarong on Muna ethnic at Masalili Village, Kontunaga District of Muna Regency has various motifs and names. In general, there are btwo motifs, namely woven sarong with horizontal lines and woven saron with box motifs. Sarong motif (lau/buri) also has several kinds like bhia-bhia sarong (bheta bhia-bhia), plain sarong (bheta poloso), ledha sarong (bheta ledha), wiu-wiu sarong ( bheta wiu-wiu), firusu sarong (bheta firusu), and lante-lante sarong (bheta lante-lante).

Woven sarong with box motifs includes kambeano bhontu sarong (bheta kambeano bhontu), bhotu sarong (bheta bhotu), dahlima sarong (bheta dahlima), kata-katamba sarong (bheta kata-katamba), kambeano kuni sarong (bheta kambeano kuni), manggo-manggopa sarong (bheta manggo-manggopa), panino toge sarong (bheta panino toge), samisili sarong (bheta samasili), bahralu sarong (bheta bharalu), kansisiri sarong (bheta kansisiri), and busarano ghai sarong (bheta busarano ghai). On Muna ethnic, mainly at Masalili Village has motifs above and it is usually differed based on the users like motif for women $(o$ robhine) and motif for men (o moghane). It can be differed cleally by looking at the motif of sarong they use (lau/buri).

\section{Conclusion}

Handicraft of Muna woven sarong (bheta wuna) at Masalili Village is one of traditional main handicrafts that still kept and developed at Muna Regency. Weaving handicraft for Munanessee gives the satisfication when they can make one woven sarong with beautiful motif. Moreover, women weavers always do innovation in creating the beautiful sarong.

Syamsumarlin, -. (2018). The Meaning and Function of Woven Sarong on Muna Community. International Journal Of Social Sciences And Humanities (IJSSH), 2(1), 56-64. doi:10.29332/ijssh.v2n1.80 
The way of Muna woven sarong making at Masalili village is done by two steps, namely arrange the thread (desoro), and weaving process (way of making) of woven sarong. It is commonly done by women, either children, girls, or older women. The function of Muna woven sarong is as culture identity, in which a certain motic can be used by only certain stratification and not for other stratification. Therefore, it can be known the stratification of Munanessee by the sarong they use, either as walaka, kaomu, or sara class.

There are also differences of the motif and meaning of Muna woven sarong between men (o moghane) and women (o robhine). It can be seen from the motif of sarong they use. Likewise, the meaning of Muna woven sarong (bheta Wuna) is symbolic creature and its meaning found in the form of "kabhantapi". Kabhantapi is upholstery of Muna woven sarong (bheta Wuna). The meaning of kabhantapi is symbolic meaning that show the stratification differences in the community or as status symbol of Munanessee.

Based on the result of this study, it recommends several issues as follow:

a) Handicraft of Muna woven sarong (bheta Wuna) is one of nation richment, so the people and government should keep and develop it as a part of national culture.

b) Munanessee, mainly at Masalili Village should develop Muna woven sarong as home industry or bigger industry and become the sentral area of weaving in Muna, Southeast Sulawesi.

c) The function and meaning of Muna woven sarong are very important to express Munanessee identity. The figures and government thus should keep and respect the use of Muna woven sarong based on the stratification.

\section{Acknowledgements}

The author would like to thank to the Cultural Faculty of Halu Oleo University and Anthropology Deparment of Halu Oleo University who give permission and help in this project, and all who contributed so much of their time and ideas, especially to Wa Ode Sitti Hafsah for her critical comments and suggestions for the improvement of this paper. 


\section{References}

1. Herusatoto, Budiono Kartiwa, and Suwati.1983. Tenun Ikat Indonesia, Djambatan, Jakarta. View in (Google Scholar)

2. Koentjaraningrat. (2005). Pengantar antropologi. Rineka Cipta. View in (Google Scholar)

3. Maran, R. R. (2000). Manusia dan Kebudayaan dalam Perspektif Ilmu Budaya Dasar. Rineka Cipta. View in (Google Scholar)

4. Melalatoa, M. J. (1995). Ensiklopedi Suku Bangsa di Indonesia Jilid LZ. Direktorat Jenderal Kebudayaan. View in (Google Scholar)

5. Melalatoa, M. J., \& Swasono, M. F. (1997). Sistem Budaya Indonesia, Diterbitkan Atas Kerjasama Fakultas Ilmu Sosial dan Politik Universitas Indonesia, PT. Pamator, Jakarta.

View in (Google Scholar)

6. Spradley, J. P. (1997). Metode Etnografi, Terjemahan Oleh Misbah Zulfa Elizabeth. Yogyakarta: Tiara Wacana Yogya.

View in (Google Scholar)

7. Wahyuni, E. T. (2015). Makna simbolis motif tenun songket aesan gede dalam prosesi pernikahan adat palembang sumatera selatan (doctoral dissertation, institut seni indonesia surakarta).

View in (Google Scholar)

8. Anwar, A., Suardika, I. K., Mursidin, T., Suleiman, A. R., \& Syukur, M. (2017). Kalosara Revitalization as an Ethno-Pedagogical Media in the Development of Character of Junior High School Students. International Education Studies, 11(1), 172.

View in (Google Scholar)

9. Winangun, Y. W. (1990). Masyarakat bebas struktur: liminalitas dan komunitas menurut Victor Turner. Penerbit Kanisius.

View in (Google Scholar)

10. Meza, A. K. T., Freyre, J. R. A., Cevallos, M. G. O., \& Pico, M. J. M. (2018). Autonomy, Good Humor and Support Networks, Potential of Community Resilience Intervention in People Victims of the Earthquake in the Calderón Parish. International Research Journal of Management, IT and Social Sciences (IRJMIS), 5(1), 1-8. View in (Google Scholar)

11. Wisudawati, N. N. S., \& Maheswari, A. I. A. (2018). Potential of Silver Craft Product through to CommunityBased for Tourism Sustainability in Celuk Village. International Research Journal of Management, IT and Social Sciences (IRJMIS), 5(1), 9-15.

View in (Google Scholar)

12. Kurniawati, E. Y., Santoso, B., \& Husnan, L. H. (2018). Budget Process of North Lombok Regency. International Research Journal of Management, IT and Social Sciences (IRJMIS), 5(2), 9-14. View in (Google Scholar)

13. Delgado, G. R. E., Meza, A. K. T., \& García, A. E. G. (2018). Resilient Factors in Students with Disabilities. International Research Journal of Management, IT and Social Sciences (IRJMIS), 5(2), 23-31. View in (Google Scholar)

Syamsumarlin, -. (2018). The Meaning and Function of Woven Sarong on Muna Community. International Journal Of Social Sciences And Humanities (IJSSH), 2(1), 56-64. doi:10.29332/ijssh.v2n1.80 
14. Mora, M. M., Espinosa, M. R., \& Delgado, M. R. (2018). Approach of Processes for the Distribution of Economic Resources in Public University of Ecuador. International Research Journal of Management, IT and Social Sciences (IRJMIS), 5(1), 25-35.

View in (Google Scholar)

15. García, B. B. B., Cedeño, H. A. C., Chica, T. K. M., \& Ríos, Y. R. P. (2018). Characterization of Auditory Disability and Its Relation to the Resilience. International Research Journal of Management, IT and Social Sciences (IRJMIS), 5(2), 15-22.

View in (Google Scholar)

16. Kusumanegara, I. S. (2018). The Analysis of Factors Constructing Employee Productivity in the Operational Field in PT. Sumber Alfaria Trijaya Branch Lombok. International Research Journal of Management, IT and Social Sciences (IRJMIS), 5(1), 55-64.

View in (Google Scholar)

17. Malaiya, S., Shrivastava, A., Prasad, G., \& Jain, P. (2017). Impact of Medical Education Trend in Community Development. International Journal of Health Sciences (IJHS), 1(1), 23-27.

View in (Google Scholar)

18. Agarwal, R., Jain, P., Ghosh, M. S., \& Parihar, K. S. (2017). Importance of Primary Health Care in the Society. International Journal of Health Sciences (IJHS), 1(1), 6-11.

View in (Google Scholar)

19. Mardika, I. N. (2017). Opposition of Community Citizenship Against the Policy of the Village's Leader. International Journal of Social Sciences and Humanities (IJSSH), 1(3), 74-87.

View in (Google Scholar)

\section{Biography of Author}

\begin{tabular}{|l|l||}
\hline & Full Name: Drs. Syamsumarlin, M.Si \\
Place/Date of Birth: Pinrang, 1st of Mey 1966 \\
Position: Lecturer of Anthropology Department and a researcher \\
Activity Now: Doctoral Student of Hasanuddin University (2014-?) \\
S-1: Anthropology Department of Hasanuddin University (1986-1991) \\
S-2: Anthropology Department of Hasanuddin University (2003-2005) \\
Address: BTN Medi Brata I Blok C/6 Kendari, Handphone: 0813417102016, \\
Author in: Walasuji Journal, Etnoreflika Journal, Journal of Sumber Daya Insani of \\
Muhammadiyah Univeristy Kendari, etc. Presenter in : national seminar and \\
meetings
\end{tabular}

